\title{
Utilization of Air Quenched Steel Slag in Decorative Ceramics with Higher Mechanical Properties
}

\author{
Xing-Mei SHEN ${ }^{1, a,{ }^{*}}$, Jun GE ${ }^{1, b}$, Hui-Hong LV²,c, Ping WANG ${ }^{2, d}$ and Liao-Sha \\ $\mathrm{LI}^{2, \mathrm{e}}$ \\ ${ }^{1}$ Key Laboratory of Metallurgical Emission Reduction \& Resources Recycling of Ministry of \\ Education, Anhui University of Technology, Ma'anshan, 243002, China
}

${ }^{2}$ AnHui Province Key Laboratory of Metallurgy Engineering \& Resources Recycling, Anhui University of Technology, Ma'anshan, 243002, China

axxxxmx@126.com, b2622872711@qq.com, c416938121@qq.com, d43736650@qq.com, eliliaosha2010@126.com

${ }^{*}$ Corresponding author

Keywords: Ceramics, Air quenched steel slag, Decorative materials, Bending strength, Vickers hardness.

\begin{abstract}
Air quenched steel slag is much more difficult to utilize than other kinds of steel slag. 50\% percent of air quenched steel slag was used to prepare brown decorative ceramics. Due to the broken $\left(\mathrm{SiO}_{4}\right)_{n}$ glass network, the optimum sintering temperature decreases with increasing $\mathrm{Na}_{2} \mathrm{O}$ and $\mathrm{MgO}$, respectively. The major crystalline phase of the samples is diopside $\left(\mathrm{CaMgSi}_{2} \mathrm{O}_{6}\right)$ with minor anorthite phase $\left(\mathrm{CaAl}_{2} \mathrm{Si}_{2} \mathrm{O}_{8}\right)$. Due to remelted glass phase, the X-ray diffraction intensity of the samples decreases with increasing $\mathrm{Na}_{2} \mathrm{O}$, while the intensity increases with increasing $\mathrm{MgO}$ which is beneficial to crystallization of the samples. The bending strength of the samples decreases with increasing $\mathrm{Na}_{2} \mathrm{O}$ (from 155.3+/-2.49 $\mathrm{MPa}$ to $143.1+/-2.01 \mathrm{MPa}$ ), while the strength increases with increasing $\mathrm{MgO}$ (from 147.4+/-3.44 MPa to 169.4+/-4.04 MPa). The Vickers hardness of the samples shows similar trends with the bending strength. The samples exhibit much better mechanical properties than marble, granite, tile and other similar ceramics reported, and present good chemical resistance. Therefore, The ceramics based on air quenched steel slag may have great potential for applications as building decorative materials, and it provides a promising way for the utilization of air quenched steel slag.
\end{abstract}

\section{Introduction}

Steel slag is a kind of intractable industrial waste, which is produced as a byproduct from either the conversion of iron to steel in basic oxygen furnace, or the melting of scrap in electric arc furnace. The chemical composition of steel slag is highly variable depending on the raw materials and production process, and the utilization of steel slag is difficult [1,2]. According to different cooling methods, air cooled steel slag, water quenched steel slag, water sprayed steel slag, air quenched steel slag, etc. are obtained respectively during the cooling process of molten slag. Since air quenched steel slag is very hard, and much more difficult to be ground than air cooled, water quenched or water sprayed steel slag, the utilization of air quenched steel slag is more difficult [3]. So far, there have been no effective ways for largely utilization of air quenched steel slag.

Air quenched steel slag contains calcium oxide, silicon dioxide, magnesium oxide and so on, which are the important component of glass ceramics. In recent years, coal combustion ash [4,5], blast furnace slag [6,7], fly ash and filter dusts from waste incinerators [8-10], mud from metal hydrometallurgy [11,12], different types of sludge $[13,14]$ and other industrial wastes $[15,16]$ have been used for the preparation of glass ceramics. Khater [17] has reported that glass ceramics based on $56.78 \%$ blast furnace slag were prepared by mixing quartz sand, dolomite, limestone and clay as other batch constituents. The glass ceramics obtained from vitrified sewage sludge have been studied by Bernardo and Dal Maschio [18], and the sample features good mechanical properties and a 
negligible release of heavy metals. Liquid-liquid mixing method was proposed by Zhang et al. [19] to prepare glass ceramics from molten water quenched steel slag, which provides a novel approach to achieve zero disposal of steel slag with utilization of the heat energy of the molten water quenched steel slag. As mentioned above, air quenched steel slag is much more difficult to utilize than other kinds of steel slag, and studies on preparation of glass ceramics based on air quenched steel slag have not been reported yet.

In this paper, glass ceramics were prepared using $50 \%$ percent of air quenched steel slag. The effects of $\mathrm{Na}_{2} \mathrm{O}$ and $\mathrm{MgO}$ on the optimum sintering temperature, crystalline phase, bending strength, Vickers hardness, chemical resistance and bulk density of the samples were investigated, and mechanical properties of the glass ceramic were compared with those of marble, granite, tile and other similar glass ceramics reported.

\section{Experimental Procedure}

\section{Preparation of Glass-Ceramics}

Air quenched steel slag used in this work was obtained from Maanshan Iron and Steel Co. Ltd., and the chemical composition of the steel slag is shown in Table 1. The steel slag was dried and pulverized before use.

Table 1. Chemical composition of air quenched steel slag. (wt\%)

\begin{tabular}{llllllllll}
\hline Component & $\mathrm{SiO}_{2}$ & $\mathrm{CaO}$ & $\mathrm{Al}_{2} \mathrm{O}_{3}$ & $\mathrm{MgO}$ & $\mathrm{Fe}_{2} \mathrm{O}_{3}$ & $\mathrm{TiO}_{2}$ & $\mathrm{MnO}$ & $\mathrm{K}_{2} \mathrm{O}$ & $\mathrm{Na}_{2} \mathrm{O}$ \\
\hline Content & 11.26 & 42.59 & 2.01 & 8.22 & 30.54 & 0.837 & 2.51 & 0.011 & 0.117 \\
\hline
\end{tabular}

The base glasses were prepared using $50 \%$ above steel slag, and the chemical composition of the base glasses, which was determined by our previous experiments, is listed in Table 2. A1, A2, A3, A4 and B1, B2, B3, B4 were, respectively, used to denote samples with different weight percent of $\mathrm{Na}_{2} \mathrm{O}$ and $\mathrm{MgO}$. According to Table 2, the mixture powders were transferred to alumina crucibles and melted at $1723 \mathrm{~K}$ for $2 \mathrm{~h}$ in an electric furnace. Then, the melts were water quenched and dried. After milling to 200 mesh, the glass powders were pressed at $35 \mathrm{MPa}$ and shaped in a steel disc with polyvinyl alcohol. Finally, the obtained compacts were heated at $673 \mathrm{~K}$ for $1.5 \mathrm{~h}$ to remove polyvinyl alcohol, and sintered at different temperature for $3 \mathrm{~h}$.

Table 2. Chemical composition of the ceramics. ( $\mathrm{wt} \%)$

\begin{tabular}{llllllll}
\hline Number & $\mathrm{SiO}_{2}$ & $\mathrm{CaO}$ & $\mathrm{Al}_{2} \mathrm{O}_{3}$ & $\mathrm{Fe}_{2} \mathrm{O}_{3}$ & others & $\mathrm{MgO}$ & $\mathrm{Na}_{2} \mathrm{O}$ \\
\hline $\mathrm{A} 1$ & 49.83 & 21.23 & 4 & 15.27 & 3.57 & 4.1 & 2 \\
$\mathrm{~A} 2$ & 49.83 & 21.23 & 4 & 15.27 & 3.57 & 4.1 & 3 \\
$\mathrm{~A} 3$ & 49.83 & 21.23 & 4 & 15.27 & 3.57 & 4.1 & 4 \\
$\mathrm{~A} 4$ & 49.83 & 21.23 & 4 & 15.27 & 3.57 & 4.1 & 5 \\
$\mathrm{~B} 1$ & 49.83 & 21.23 & 4 & 15.27 & 3.57 & 5 & 5 \\
$\mathrm{~B} 2$ & 49.83 & 21.23 & 4 & 15.27 & 3.57 & 6 & 5 \\
$\mathrm{~B} 3$ & 49.83 & 21.23 & 4 & 15.27 & 3.57 & 7 & 5 \\
$\mathrm{~B} 4$ & 49.83 & 21.23 & 4 & 15.27 & 3.57 & 8 & 5 \\
\hline
\end{tabular}

\section{Characterization}

The chemical composition of the samples was determined by ARL Advant X Intellipower 3600 X-ray fluorescence (XRF). The structure of the samples was characterized by Bruker AXS-D8 Advance $\mathrm{X}$-ray powder diffraction (XRD) using $\mathrm{Cu} \mathrm{K \alpha}$ radiation $(\lambda=0.15405 \mathrm{~nm}$ ) operated at $40 \mathrm{kV}$ and 40 $\mathrm{mA}$. The morphology of the samples was observed by HITACHI S4300 scanning electron microscope (SEM) after polishing and etching in 5\% HF solution for $20 \mathrm{~s}$. The bending strength was measured by three point bending method, and the average value was obtained from measurements of 
five samples. The Vickers hardness of the samples was measured by Vickers tester (Buehler, micrometel). The chemical resistance was examined in acid and alkali solutions. The samples were immersed respectively in $\mathrm{H}_{2} \mathrm{SO}_{4}(1 \mathrm{mass} \%)$ solution and $\mathrm{NaOH}(1 \mathrm{mass} \%)$ solution for $24 \mathrm{~h}$, then, washed with deionized water, dried at $393 \mathrm{~K}$ for $12 \mathrm{~h}$ and weighed. The chemical resistance of the samples was determined by the weight difference before and after the chemical resistance test. The bulk densities of the samples were measured by the Archimedes method using water.

\section{Results and Discussion}

Fig. 1 shows the relationships between the optimum sintering temperature of the samples and content of $\mathrm{Na}_{2} \mathrm{O}, \mathrm{MgO}$ respectively. The optimum sintering temperature is determined by XRD patterns, density and appearance of the samples as shown in Table 3. The samples sintering at optimum temperature provide brown colour due to a certain amount of iron oxide and possess smooth surface and high gloss. However, samples sintering below optimum temperature present rough and uneven surface. With the increase of sintering temperature, the surface of the samples became smooth, and the samples showed an overfiring behaviour when sintered above optimum temperature about $20 \mathrm{~K}$, owing to rapid decrease in glass viscosity, and the shape of the samples can not be maintained. From Fig. 1(a), it can be seen that the optimum sintering temperature of the samples decreases with the increase of $\mathrm{Na}_{2} \mathrm{O}$. As alkali oxides, $\mathrm{Na}_{2} \mathrm{O}$ provides free oxygen ions which can break large $\left(\mathrm{SiO}_{4}\right)_{\mathrm{n}}$ glass network in the samples [20,21]. Then, the glass viscosity decreases with increasing $\mathrm{Na}_{2} \mathrm{O}$, and consequently, the mass transfer process is accelerated. Therefore, the samples can be sintered at lower temperature. The optimum temperature of the samples also decreases with increasing $\mathrm{MgO}$, as shown in Fig. 1(b). This is because that $\mathrm{MgO}$, which is a well-known glass network modifier, may cause the glass network structure to loosen [22]. The loosened network facilitates the diffusion of ions, the sintering temperature of the samples, hence, can be decreased.
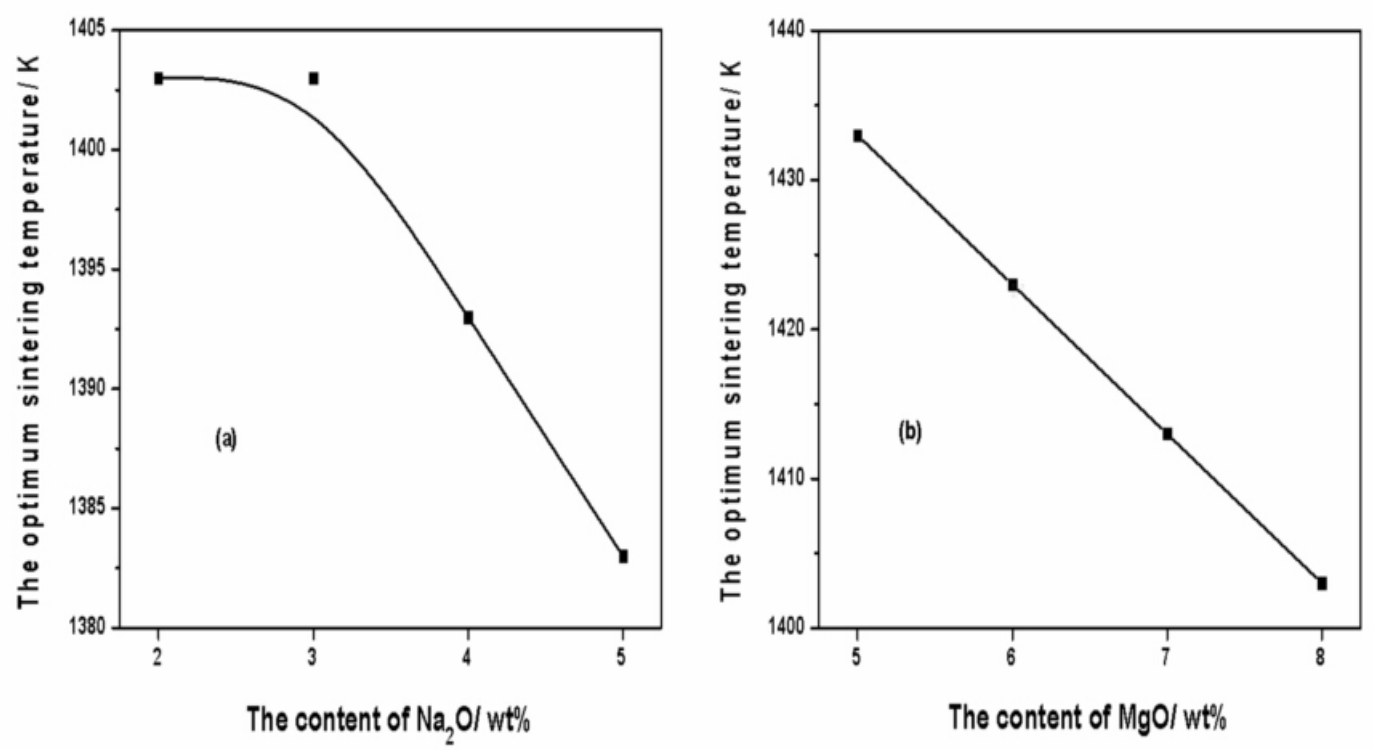

Fig. 1. The relationship between the optimum sintering temperature of the samples and content of $\mathrm{Na}_{2} \mathrm{O}, \mathrm{MgO}$ respectively. 
Table 3. Density and appearance of the samples sintering at different temperatures.

\begin{tabular}{llll}
\hline \multirow{2}{*}{ Number } & $\begin{array}{l}\text { Sintering } \\
\text { temperature }(\mathrm{K})\end{array}$ & $\begin{array}{l}\text { Density } \\
\left(\mathrm{g} / \mathrm{cm}^{3}\right)\end{array}$ & Appearance of the samples \\
\hline \multirow{3}{*}{ A1 } & 1373 & 2.80 & brown colour, rougher surface \\
& 1383 & 2.80 & brown colour, rough surface \\
& 1393 & 2.82 & brown colour, relatively smooth surface \\
& 1403 & 2.83 & brown colour, smooth surface, high gloss \\
A2 & 1373 & 3.08 & brown colour, rougher surface \\
& 1383 & 3.08 & brown colour, rough surface \\
& 1393 & 3.08 & brown colour, relatively smooth surface \\
& 1403 & 3.09 & brown colour, smooth surface, high gloss \\
A3 & 1373 & 2.85 & brown colour, rough surface \\
& 1383 & 2.87 & brown colour, relatively smooth surface \\
& 1393 & 2.90 & brown colour, smooth surface, high gloss \\
& 1403 & 2.90 & brown colour, smooth surface, higher gloss \\
A4 & 1373 & 2.91 & brown colour, relatively smooth surface \\
& 1383 & 2.93 & brown colour, smooth surface, high gloss \\
& 1393 & 2.93 & brown colour, smooth surface, higher gloss \\
& 1403 & - & brown colour, more glass phase, overfiring \\
\hline \multirow{3}{*}{ B1 } & 1403 & 2.85 & brown colour, rougher surface \\
& 1413 & 2.87 & brown colour, rough surface \\
& 1423 & 2.87 & brown colour, relatively smooth surface \\
& 1433 & 2.87 & brown colour, smooth surface, high gloss \\
& 1403 & 2.90 & brown colour, rough surface \\
B2 & 1413 & 2.91 & brown colour, relatively smooth surface \\
& 1423 & 2.93 & brown colour, smooth surface, high gloss \\
& 1433 & 2.93 & brown colour, smooth surface, higher gloss \\
& 1403 & 2.97 & brown colour, relatively smooth surface \\
& 1413 & 2.98 & brown colour, smooth surface, high gloss \\
& 1423 & 2.98 & brown colour, smooth surface, higher gloss \\
& 1433 & - & brown colour, more glass phase, overfiring \\
& 1403 & 2.97 & brown colour, smooth surface, high gloss \\
& 1413 & 2.97 & brown colour, smooth surface, higher gloss \\
& 1433 & - & brown colour, more glass phase, overfiring \\
& & & \\
\hline
\end{tabular}

Fig. 2 shows the X-ray diffraction patterns of A2, A4, B2 and B4 samples, obtained by sintering at $1403 \mathrm{~K}$ for $3 \mathrm{~h}$. As can be seen from the figure, the major crystalline phase is diopside $\left(\mathrm{CaMgSi}_{2} \mathrm{O}_{6}\right.$, JCPDS Card, No. 11-0654) with minor anorthite phase $\left(\mathrm{CaAl}_{2} \mathrm{Si}_{2} \mathrm{O}_{8}\right.$, JCPDS Card, No. 03-0505) for all of the samples. Diopside possesses good wear resistance, chemical resistance and impact resistance $[23,24]$. Note that, the diffraction intensity of A2 is higher than that of A4. This is because that the glass network of the samples can be partly broken by $\mathrm{Na}_{2} \mathrm{O}$, which decreases viscosity of the glass and the maximum crystalline temperature. With the increase of $\mathrm{Na}_{2} \mathrm{O}$, the range between sintering temperature and maximum crystalline temperature is increased, indicating that the remelted glass phase is increasing. For A4, the crystalline phase is partly reconverted to glass phase at $1403 \mathrm{~K}$, and the diffraction intensity is reduced. Hence, sintering temperature can be reduced by adding $\mathrm{Na}_{2} \mathrm{O}$ as shown in Fig. 1(a), but remelting process of glass phase is accelerated simultaneously, which has adverse influence on crystallization of the samples. For B2 and B4, the crystalline phases are more than those of $\mathrm{A} 2$ and $\mathrm{A} 4$ under the same heat treatment, indicating that $\mathrm{MgO}$ is beneficial to crystallization of the samples. Though the glass network structure is loosened by $\mathrm{MgO}$, higher electric field intensity of $\mathrm{Mg}^{2+}$ will induce local accumulation in glass network structure, which accelerates crystallization of the samples. 


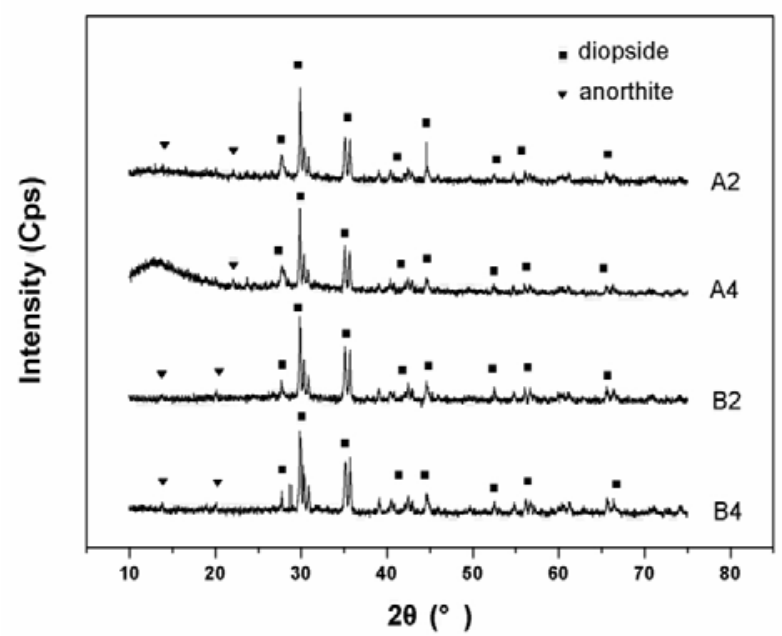

Fig. 2. The XRD patterns of A2, A4, B2 and B4 samples obtained by sintering at $1403 \mathrm{~K}$ for $3 \mathrm{~h}$.

SEM images of A4 and B4 samples are shown in Fig. 3(a) and Fig. 3(b), respectively. As can be seen in the figure, spherical diopside grains with the size of $0.5 \sim 1 \mu \mathrm{m}$ and tabular anorthite grains were randomly distributed in both samples. Anorthite grains are much less than diopside ones. Besides dispersed small grains, a few larger spherical diopside grains about $3 \mu \mathrm{m}$ were observed, and the larger diopside grains in B4 are much less than those in A4.
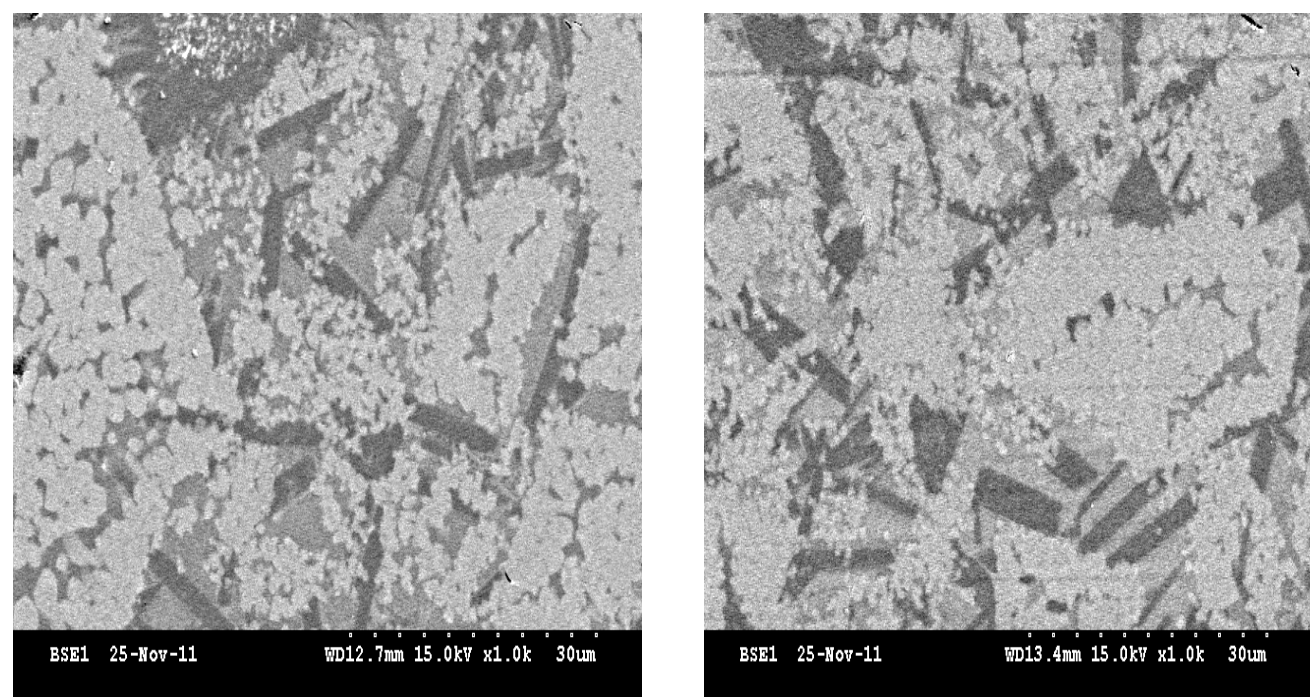

Fig. 3. SEM images of A4 and B4 samples.

Fig. 4 shows the relationships between the bending strength, Vickers hardness of the samples and the content of $\mathrm{Na}_{2} \mathrm{O}, \mathrm{MgO}$ respectively. As can be seen in Fig. 4(a), the bending strength decreases from $155.3+/-2.49 \mathrm{MPa}$ to $143.1+/-2.01 \mathrm{MPa}$ with the increase of $\mathrm{Na}_{2} \mathrm{O}$. It is known that bending strength and other mechanical properties of the samples depend, in general, on the amount of the major crystalline phase. Due to the decrease of diopside phase shown in Fig, 2, bending strength of the samples is decreasing with $\mathrm{Na}_{2} \mathrm{O}$. The Vickers hardness of the samples decreases with increasing $\mathrm{Na}_{2} \mathrm{O}$ (from $7.83+/-0.0158 \mathrm{GPa}$ to $7.48+/-0.0141 \mathrm{GPa}$ ) for similar reasons with the bending strength results. From Fig. 4(b), it can be seen that the bending strength and Vickers hardness of the samples increase with increasing $\mathrm{MgO}$, from 147.4+/-3.44 MPa to 169.4+/-4.04 MPa and 7.58+/-0.0071 GPa to $7.98+/-0.0735 \mathrm{GPa}$, respectively, which is also consistent with increasing diopside phase results. 

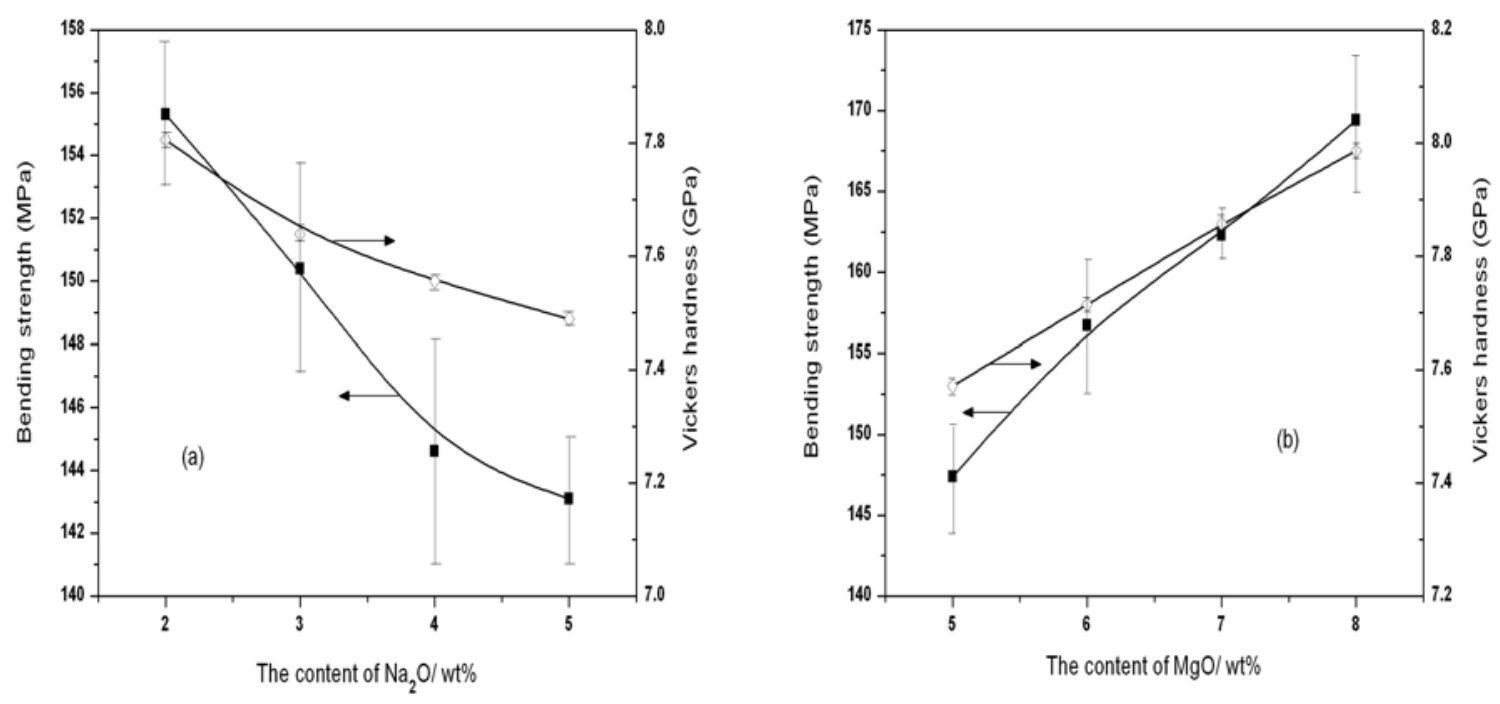

Fig. 4. The relationships between the bending strength, Vickers hardness of the samples and the content of $\mathrm{Na}_{2} \mathrm{O}, \mathrm{MgO}$ respectively.

The bending strength and Vickers hardness of marble, granite, tile, glass ceramic prepared by Toya, et al. [25], and B4 sample are listed in Table 4. Comparing these mechanical data, it can be seen that glass-ceramic based on air quenched steel slag (B4 sample) exhibits much better mechanical properties than other decorative materials. The chemical resistance and bulk density of the samples are shown in Table 5. The samples exhibit good chemical resistance, and the weight loss values in acid are obviously lower than those in alkali, and the bulk density of the samples ranges from 2.83 $\mathrm{g} / \mathrm{cm}^{3}$ to $3.09 \mathrm{~g} / \mathrm{cm}^{3}$. Therefore, the glass ceramics based on air quenched steel slag may have great potential for applications as building decorative materials.

Table 4. Bending strength and Vickers hardness of marble, granite, tile, other similar glass ceramic reported and B4 sample.

\begin{tabular}{llllll}
\hline $\begin{array}{l}\text { Mechanical } \\
\text { properties }\end{array}$ & Marble & Granite & Tile & $\begin{array}{l}\text { Glass ceramic } \\
\text { in Ref. [25] }\end{array}$ & $\begin{array}{l}\text { B4 } \\
\text { sample }\end{array}$ \\
\hline $\begin{array}{l}\text { Bending } \\
\begin{array}{l}\text { Strength (MPa) } \\
\text { Vickers }\end{array}\end{array}$ & $13-15$ & $15-38$ & $24-30$ & 130 & 169.4 \\
hardness (GPa) & $3.0-5.0$ & 5.5 & 6.5 & 7.4 & 7.98 \\
\hline
\end{tabular}

Table 5. Chemical resistance and bulk density of the glass ceramics based on air quenched steel slag.

\begin{tabular}{llll}
\hline Number & $\begin{array}{l}\text { Weight loss } \\
\text { in acid }(\%)\end{array}$ & $\begin{array}{l}\text { Weight loss } \\
\text { in alkali }(\%)\end{array}$ & $\begin{array}{l}\text { Bulk density } \\
\left(\mathrm{g} / \mathrm{cm}^{3}\right)\end{array}$ \\
\hline A1 & 0.05 & 0.20 & 2.83 \\
A2 & 0.05 & 0.19 & 3.09 \\
A3 & 0.08 & 0.19 & 2.90 \\
A4 & 0.1 & 0.18 & 2.93 \\
B1 & 0.03 & 0.15 & 2.87 \\
B2 & 0.03 & 0.13 & 2.93 \\
B3 & 0.02 & 0.12 & 2.98 \\
B4 & 0.015 & 0.12 & 2.97 \\
\hline
\end{tabular}




\section{Summary}

Brown glass ceramics were prepared using $50 \%$ percent of air quenched steel slag. The major crystalline phase of the samples is diopside $\left(\mathrm{CaMgSi}_{2} \mathrm{O}_{6}\right)$ with minor anorthite phase $\left(\mathrm{CaAl}_{2} \mathrm{Si}_{2} \mathrm{O}_{8}\right)$. Due to the broken $\left(\mathrm{SiO}_{4}\right)_{n}$ glass network, the optimum sintering temperature decreases with the increasing $\mathrm{Na}_{2} \mathrm{O}$ and $\mathrm{MgO}$, respectively. The bending strength and Vickers hardness of the samples decrease with $\mathrm{Na}_{2} \mathrm{O}$ while increasing with $\mathrm{MgO}$, and are much better than those of marble, granite, tile and other similar glass ceramics reported. The glass ceramics based on air quenched steel slag may have great potential for applications as building decorative materials, and it provides a promising way for the utilization of air quenched steel slag.

\section{Acknowledgement}

This research was financially supported by the National Science Foundation (grant 51302003), Natural Science Foundation of Anhui Province (No. 1708085ME119), University Science Research Project of AnHui Province (KJ2017A050) and Anhui innovation team project of new technology in materialization of metallurgical solid wastes.

\section{References}

[1] P.E. Tsakiridis, G.D. Papadimitriou, S. Tsivilis, C. Koroneos, Utilization of steel slag for Portland cement clinker production, J. Hazard. Mater. 152 (2008) 805-811.

[2] I.A. Altun, I. Yilmaz, Study on steel furnace slags with high $\mathrm{MgO}$ as additive in Portland cement, Cem. Concr. Res. 32 (2002) 1247-1249.

[3] C. Shi, Steel Slag-Its Production, Processing, Characteristics, and Cementitious Properties, J. Mater. Civ. Eng. 16 (2004) 230-236.

[4] M. Erol, S. Küëükbayrak, A. Ersoy-Mericboyu, Comparison of the properties of glass, glass-ceramic and ceramic materials produced from coal fly ash, J. Hazard. Mater. 153 (2008) 418-425.

[5] F. Peng, K. Liang, A. Hu, Nano-crystal glass-ceramics obtained from high alumina coal fly ash, Fuel. 84 (2005) 341-346.

[6] H. Liu, H. Lu, D. Chen, H. Wang, H. Xu, R. Zhang, Preparation and properties of glass-ceramics derived from blast-furnace slag by a ceramic-sintering process, Ceram. Int. 35 (2009) 3181-3184.

[7] B. Das, S. Prakash, P.S.R. Reddy, V.N. Misra, An overview of utilization of slag and sludge from steel industries, Resour. Conserv. Recy. 50 (2007) 40-57.

[8] I. Rozenstrauha, D. Bajare, R. Cimdins, L. Berzina, J. Bossert, A.R. Boccaccini, The influence of various additions on a glass-ceramic matrix composition based on industrial waste, Ceram. Int. 32 (2006) 115-119.

[9] Y.J. Park, J. Heo, Corrosion behavior of glass and glass-ceramics made of municipal solid waste incinerator fly ash, Waste Manage. 24 (2004) 825-830.

[10] G. Qian, Y. Song, C. Zhang, H. Zhang, P. Chui, Diopside-based glass-ceramics from MSW fly ash and bottom ash, Waste Manage. 26 (2006) 1462-1467.

[11] J. Yang, D. Zhang, J. Hou, B. He, B. Xiao, Preparation of glass-ceramics from red mud in the aluminium industries, Ceram. Int. 34 (2008) 125-130.

[12] F. Peng, K. Liang, H. Shao, A. Hu, Nano-crystal glass-ceramics obtained by crystallization of vitrified red mud, Chemosphere. 59 (2005) 899-903. 
[13] T. Toya, Y. Kameshima, A. Nakajima, K. Okada, Preparation and properties of glass-ceramics from kaolin clay refining waste (Kira) and paper sludge ash, Ceram. Int. 32 (2006) 789-796.

[14] T. Toya, A. Nakamura, Y. Kameshima, A. Nakajima, K. Okada, Glass-ceramics prepared from sludge generated by a water purification plant, Ceram. Int. 33 (2007) 573-577.

[15] G.A. Khater, Glass-ceramics in the $\mathrm{CaO}-\mathrm{MgO}-\mathrm{Al}_{2} \mathrm{O}_{3}-\mathrm{SiO}_{2}$ system based on industrial waste materials, J. Non-Cryst. Solids. 356 (2010) 3066-3070.

[16] E. Bernardo, R. Castellan, S. Hreglich, Sintered glass-ceramics from mixtures of wastes, Ceram. Int. 33 (2007) 27-33.

[17] G.A. Khater, Influence of $\mathrm{Cr}_{2} \mathrm{O}_{3}, \mathrm{LiF}, \mathrm{CaF}_{2}$ and $\mathrm{TiO}_{2}$ nucleants on the crystallization behavior and microstructure of glass-ceramics based on blast-furnace slag, Ceram. Int. 37 (2011) 2193-2199.

[18] E. Bernardo, R. Maschio, Glass-ceramics from vitrified sewage sludge pyrolysis residues and recycled glasses, Waste Manage. 31 (2011) 2245-2252.

[19] K. Zhang, J. Liu, W. Liu, J. Yang, Preparation of glass-ceramics from molten steel slag using liquid-liquid mixing method, Chemosphere. 85 (2011) 689-692.

[20] H. Kim, I. Sohn, Effect of $\mathrm{CaF}_{2}$ and $\mathrm{Li}_{2} \mathrm{O}$ Additives on the Viscosity of $\mathrm{CaO}-\mathrm{SiO}_{2}-\mathrm{Na}_{2} \mathrm{O}$ Slags, ISIJ Int. 51 (2011) 1-8.

[21] H. Takebe, T. Murata, K. Morinaga, Compositional Dependence of Absorption and Fluorescence of $\mathrm{b}^{3+}$ in Oxide Glasses, J. Am. Ceram. Soc. 79 (1996) 681-687.

[22] K. Singh, N. Gupta, O.P. Pandey, Effect of $\mathrm{Y}_{2} \mathrm{O}_{3}$ on the crystallization behavior of $\mathrm{SiO}_{2}-\mathrm{MgO}-\mathrm{B}_{2} \mathrm{O}_{3}-\mathrm{Al}_{2} \mathrm{O}_{3}$ glasses, J. Mater. Sci. 42 (2007) 6426-6432.

[23] D.U. Tulyaganov, Phase Equilibrium in the Fluorapatite-Anorthite-Diopside System, J. Am. Ceram. Soc. 83 (2000) 3141-3146.

[24] J.L. Sun, C.X. Liu, X.H. Zhang, B.W. Wang, X.Y. Ni, Effect of diopside addition on sintering and mechanical properties of alumina, Ceram. Int. 35 (2009) 1321-1325.

[25] T. Toya, Y. Tamura, A. Nakajima, Y. Kameshima, K. Okada, Preparation and properties of $\mathrm{CaO}-\mathrm{MgO}-\mathrm{Al}_{2} \mathrm{O}_{3}-\mathrm{SiO}_{2}$ glass-ceramics from kaolin clay refining waste (Kira) and dolomite, Ceram. Int. 30 (2004) 983-989. 